\title{
Archipel
}

ARCHIPEL Études interdisciplinaires sur le monde insulindien

99 | 2020

Varia

\section{The Maiden in the Forest: Reflections on Some Southeast Asian Tales}

La jeune fille dans la forêt: réflexions sur quelques contes d'Asie du Sud-Est

\section{Robert Wessing}

\section{(2) OpenEdition \\ 1 Journals}

\section{Electronic version}

URL: http://journals.openedition.org/archipel/1691

DOI: 10.4000/archipel.1691

ISSN: 2104-3655

\section{Publisher}

Association Archipel

\section{Printed version}

Date of publication: 15 July 2020

Number of pages: $75-105$

ISBN: 978-2-910513-83-2

ISSN: 0044-8613

\section{Electronic reference}

Robert Wessing, "The Maiden in the Forest: Reflections on Some Southeast Asian Tales", Archipel [Online], 99 | 2020, Online since 02 June 2020, connection on 15 March 2021. URL: http:// journals.openedition.org/archipel/1691 ; DOl: https://doi.org/10.4000/archipel.1691 


\section{ÉTUDES}

\section{The Maiden in the Forest: Reflections on Some Southeast Asian Tales}

\section{Introduction $^{2}$}

In this article I look at various Southeast Asian stories from especially Central and East Java and Sunda (West Java) but also Bali, Madura, Malaysia and, where relevant, India, ${ }^{3}$ in order to discover whether a common core of ideas underlies these seemingly different tales. On one level the stories are about the origin or discovery of rice, and the rise of royal houses. By looking at the nature of some of the protagonists, and especially the context of their actions, another level will become apparent that speaks about the understandings of the peoples whose tales these are and about their position vis-à-vis nature and the supernatural world. These are deep understandings of which people perhaps

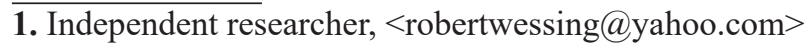

2. Many thanks to Dr. Rosemary Gianno, Dr. Jos Platenkamp, and Mr. Randall Baier for their inputs, comments, and support as the ideas explored here took form, and to Archipel's anonymous readers who caused me to rethink and clarify several points.

3. With occasional reference to stories told elsewhere in the Indonesian archipelago and in South and Southeast Asia. The themes explored here are indeed found throughout Southeast Asia, India and some as far away as Japan. This is not surprising, given the long history of trade and cultural exchange throughout the South, Southeast, and East Asia areas, nor is the fact that once transmitted stories take on local color and meaning. Such similarities combine to form the idea of what Mus (1975) called a Monsoon Asia. See also De Josselin de Jong (1935) and Abahalin (2011) for respectively a more restricted and a wider perspective. The stories were published between 1881 and 2004 , though sadly no information is available when or where and on what occasion they were collected. 
are or were not always fully consciously aware, and which were, therefore, not stated explicitly. Indeed, as the Spanish philosopher José Ortega y Gasset observed ${ }^{4}$ such not-stated understandings, which he characterizes as silences, are an essential part of language. Without them it would be impossible to say anything as every aspect would have to be explained in infinite detail. These silences are found in all languages, though what remains unspoken varies between them. Depending on the narrative, much is therefore often left to the listener to fill in. This gives narratives some flexibility, allowing them to be tailored to the need of the moment. How great this flexibility is of course depends on the importance of the narrative to the community.

I am not concerned here with sharply differentiating between various types of stories like myths, folk tales, sagas, and the like, which are in any case often difficult to tell apart. A narrative that appears as a myth in i.e. a hikayat or babad (history, chronicle) or a wayang story (puppet/shadow play) (cf. Pleyte 1905; Ajip Rosidi 1973; Wessing 2006a: 41, note 42.), may in another context be presented as a folktale in a children's book. Its presentation in the former context can surround it with an aura of sacredness which it might not have in the latter, and which is not necessarily part of the story itself. ${ }^{5}$ Yet when we compare the tales themselves, they often do not differ significantly. For clarity's sake I shall refer to them all as stories, tales or narratives, ignoring the question of their intended purpose on any one occasion.

For our purposes these are all narrations that shape the listeners' (or readers') perceptions about the nature of their local reality, thereby creating a 'truth' in which the members of the community participate, which marks them as members of the local community. In other words, narratives shape people's understanding of the world and are the basis for their social identities: we 'come to be who we are ... by being located or locating ourselves ... in social narratives rarely of our own making' (Somers 1994: 606). I would amend this by observing that while most indeed do not make up the tales, all are nevertheless active participants in shaping them, in that on hearing a tale and its silences, all must construct their own understanding of it. In effect, they create their own version of the story, which can lead to considerable variation. Thus even locally more than one version of a narrative can exist and be regarded as true. Also, not all participants necessarily and unquestioningly accept the truth of any one version. Through listening to or retelling the tales we reconstruct them and make them our own. Even doubters generally know the tales and must take them into consideration when participating in the community.

4. Cited by A.L. Becker (1995:6).

5. See for instance the story of Nyai Rara Kidul in Olthof (1987), where it is part of the Babad Tanah Jawi, and in children's books such as HAR (n.d.) or Subiyanto (n.d.), or, further afield, in films about her (Wessing 2007). 
The assumption underlying this article, therefore, is that the stories analyzed here reflect some fundamental aspects of society, some obvious, others more hidden, that were accepted as evident truths, at least at a time in the past, even if they have now fallen into disuse or even disrepute. These include not just features of the social and physical environments, but also encompass the realm of the spirits or the world of the gods. Since this realm cannot be known through the senses, it is given reality through narratives created to account for it, narratives and thus also a reality, that may change over time and with the social context in which the narratives are told. Thus the 'reality' of e.g. spirits varies considerably over time and between different categories of observers, some of whom, perhaps decreasingly, 'experience' them as forces, both benign and dangerous and sometimes both simultaneously (Wessing 2006a) while others, perhaps increasingly, consider them to be nonsense or, if real, to be enemies of new religious and cosmological priorities, contact with which is best avoided (cf. Wessing 2013:115-116.) ${ }^{6}$

The narratives considered here can be roughly divided into two categories, ${ }^{7}$ namely stories about the origin or discovery of rice, and romances about princes and their rise to power. The tales about rice can furthermore be subdivided into ones dealing with the courts of Java, and those about villagers and their encounter with wondrous maidens that for a time bring them welfare and ease. These divisions are only very general ones, however, as elements from one category can and often do appear in other tales.

\section{The Origin of the Rice Goddess}

The tales Sulanjana from Sunda (West Java) (Hidding 1929; Van der Horst van Doorn 1929:123-127) ${ }^{8}$ and Mengukuhan from Java proper (Rassers 1959:14-9) both account for the arrival of rice as a human food. In the Sulanjana tale, the action begins when the god Guru orders all the gods to participate in a construction project. All set out to do so except the snake god Antaboga, who cries and laments that he cannot possibly obey because he has no hands or feet. His tears turn into three eggs, which he is told to offer to Guru. This

\footnotetext{
6. It should be pointed out that in East Java this idea that contact with spirits is best avoided was expressed to me by both Muslim informants and Pentecostal ones, the latter calling those dealing with spirits (pawang, dhukun) devil worshippers. This should not be taken to mean that all Muslims and Christians avoid contacts with such practitioners. Rather, while religious teachings may discourage or forbid it, many still use the putative skills or other remedial powers these individuals are believed to have when looking for solutions to their problems.

7. Considerations of space force me to relate the tales only in outline, referring the reader to published versions for greater detail.

8. The stories retold by Van der Horst van Doorn (1929) should be approached with some caution as elements are found in them that are not found in the Indonesian and scholarly Dutch treatments, giving the impression that they were smoothed out for the Dutch readers of the time.
} 
he sets out to do, encountering some obstacles on the way in which two of the eggs are broken. He finally surrenders the last egg to Guru, who tells him to see to its incubation. After some time a beautiful maiden, Tisnawati, emerges from the egg, who is adopted by Guru and his wife. Later Guru falls in love with his adopted daughter and proposes to marry her.

The Javanese version, Mengukuhan, starts with Kanekaputra in possession of a wondrous jewel, the Retna dumilah. In the realm of the gods, Guru pressures him to show him the jewel. Reluctantly Kanekaputra throws it to Guru, who fails to catch it. The falling jewel is swallowed by Antaboga, who is meditating in the middle of the ocean. The gods search high and low for the jewel until they finally come to Antaboga, who refuses to give it up. The gods then attempt to take Antaboga to Guru, jewel and all, at which Antaboga goes there on his own. He produces the jewel which is encased in a box that none can open. Guru finally throws it down and from it a beautiful maiden appears, Tisnawati, whom Guru later either marries or wants to marry. In both narratives Tisnawati makes certain demands before the marriage can be consummated, including a food that once eaten, will forever satisfy. While the story does not say so explicitly, this is probably a reference to rice. Guru then orders one of the gods, bathara Kalagumarang, to fulfill Tisnawati's wishes.

With that, the activities move to earth, where the searching Kalagumarang happens upon the goddess Dewi Sri, the wife of the god Vishnu, bathing in the garden Banjaran sari. Smitten, he pursues her, even demanding that Vishnu surrender his wife to him. At this Vishnu and Sri disappear, incarnating as the king and queen of the realm of Mendangkamulan, while Kalagumarang turns into a pig. All these delays frustrate Guru who, unable to contain himself, eventually violates Tisnawati, who dies as a result. In the Sulanjana tale, she dies of hunger, waiting for the food Kalagumarang was sent to fetch.

Filled with remorse Guru recalls Kalagumarang, and orders Tisnawati to be buried in a clearing in the forest in the kingdom of Mendangkamulan. ${ }^{9}$ There, miraculously, a coconut palm grows from her head, followed by rice growing from her genitals, and bananas, maize, bamboo, an arenga palm and many other kinds of plants growing from other parts of her body. The pig Kalagumarang ${ }^{10}$ and his offspring turn into the pests that still threaten the rice and other crops today.

In the Sulanjana tale the action then moves to the Sundanese kingdom of Pajajaran, whose king, Prabu Siliwangi, is to supervise the care of the rice crop, now known as Nyi Pohaci Sangyang Sri. His wife, the widadari (nymph) Dewi Nawang Wulan Sasih (Nawang of the Full Moon) instructs the

9. Kamulan from mula (beginning, original). Kats (1916:179) writes Kamulyan, from mulya (prosperity, honor, esteem) (Robson and Wibisono 2002:498).

10. Elsewhere, however, Gumarang is the name of a mythological ox (Robson and Wibisono 2002:270). 
women in cooking this miracle crop, one stalk of which will feed a hundred persons. One instruction she gives is that the king, her husband, is never to touch the kitchen equipment. If he does so, they will immediately be divorced and the magic of the rice would disappear. ${ }^{11}$ This last detail will reappear in other tales, as will the bathing in the garden by Dewi Sri.

\section{Sri Mahapunggung}

This Javanese narrative is more specifically about Dewi Sri, the rice goddess. As the tale opens, Dewi Sri is fully grown and lives in the palace of Mendangkamulan, clearly an earthly kingdom. A discussion is ongoing about the whereabouts of her brother, prince Sedana, who has been missing for a while. Messengers arrive, bearing a proposal from the powerful king Pulagra that he be married to Dewi Sri. Dewi Sri, however, firmly rejects the idea, even at the cost of her life. Angered, the king exiles her to the wilderness, telling Pulagra's emissaries that they can have her if they can catch her.

This notion of exile to the wilderness and generally the differentiation between village or realm and the forest discussed in these tales should not be understood as one of total opposition. Indeed some overlap between them had to exist for communication between humans and forest denizens to be possible. In India, Schnepel (1995: 158) writes, there is a differentiation between vana and kșetra, wilderness and settled space, which 'occupy two complementary poles on a continuum in the people's experience of their habitat and of the various forces associated with it.' The wilderness, then, is part of human social space, so that exile to it did not mean a total exclusion from social life. It is just the space occupied by the spirits who, while not totally without order, maintained rules of their own that did not necessarily correspond to those of the human community (cf. Schefold 1989). The forests, furthermore, were differentiated into two or even three separate domains, the hutan pinggir near villages, home of the tutelary spirit and the community's (tiger) guardian. Further away, transitioning into the mountain slopes, was the 'real' forest (alas), where the forest spirits were found. The forest on the mountain slopes, finally, was where aspiring kings went to meditate and gain cosmic powers (kasekten) (Wessing 2006a: 25-6; Lombard 1974: 477). The forest, therefore, should not be thought of as the impenetrable tangle of brush and trees of the cinematic imagination, populated by fierce tigers and fearsome snakes. Although some stretches of forest, especially near streams, might be tangled, swampy, muddy and slippery, it often also consisted of wooded areas interspersed with open grassland, while wild animals seemed to favor the

11. Hazeu (1901:39) calls Nini Towong the patron saint of kitchens, reminiscent of Nawang Wulan, Tisnawati and Dewi Sri and the behavioral rules they instituted, e.g. excluding men from participating in kitchen activities, and maintaining cleanliness (Purwadi 2004: 137; Rassers 1959: 11). 
jungle's edge (see the plates in Nieuwenhuys and Jaquet 1980; Termorshuizen 1993: 40, 72, 80; Chapman 1973:65. 361).

Dewi Sri having been exiled, the scene switches to a farmer and his wife discussing the care of the newly harvested rice crop. Suddenly Dewi Sri appears in their rice-husking mortar (lesung). The farmers invite her into the house, but are told to first clean the place. This done Dewi Sri enters the house and drinks a draught of coconut juice. Just as she gets ready to leave, her pursuers arrive, demanding that she come to Pulagra's palace. They quickly overpower the farmer, as Dewi Sri flees from the fight.

Enter the gods Guru and Nerada who quickly assess the situation. Nerada directs Dewi Sri to where her missing brother Sedana is living in the forest of Mendangagung. While Dewi Sri tells Sedana all that has happened, her pursuers once more arrive, demanding that she come along. Sedana refuses to comply and a fight ensues which Sedana wins. The two then decide to found a settlement in the forest of Mendangagung for which Dewi Sri sends Sedana to fetch seeds, coconuts, rice, root crops, eggplant, and spices. To these Sedana adds fencing materials and some labor. The requested supplies soon arrive. Then Dewi Sri sends her brother to fetch the couple who had received her in their home. The farmer, still tied up, is freed, and he and his wife head for the new settlement.

In the meantime, Pulagra's returned emissaries report their misadventures, causing king Pulagra to set off himself, along with all his nobles. As Dewi Sri welcomes her farmer friends, king Pulagra and his men arrive, and a battle royal ensues which king Pulagra loses. Now Guru and Nerada reappear, telling Dewi Sri and Sedana to marry. Both refuse, saying they will only marry if their partner looks like his or her sibling, although they also refuse to marry each other. At this they are separated and the narrative, rather abruptly, ends.

At first glance this last tale doesn't really seem to go anywhere, until one looks more closely at the figures themselves. First of all, as Kats (1916:188) points out, in Indian mythology Sri is the śakti (female generative power, also wife) of the god Vishnu, while Sâdhana is one of Vishnu's names. ${ }^{12}$ In other tales about Sri and Sedana (Kats 1916:186), both she and her brother came out of two of the eggs that were incubated by Antaboga. As was told above, Dewi Sri was cared for by Dewi Uma, Guru's wife, while Sedana's care-giver was the god Nerada. However, both care-givers erred in the performance of their task, causing their charges to die. Sedana's body then became the source of iron, precious metals, diamonds and the like, while Dewi Sri's body

12. Sâdhana means among other things wealth and money (Zoetmulder 1982, II:1586). Vishnu's wife is Lakshmi or Sri, the goddess of fortune (Dowson 1972:361). Since, therefore, in the realm of the gods Vishnu and Sri are man and wife, the separation of Sri and Sedana is more apparent than real. As Kats (1916:189) points out, this explains the inseparability of the two and the fact that Sri searched everywhere for Sedana. 
produced all kinds of seeds, ${ }^{13}$ much like was told of Tisnawati's body after her burial. In yet another tale, as Dewi Sri flees from Kalagumarang, she suddenly disappears. At the place where she was last seen, the same plants then grow that earlier were said to have grown from Tisnawati's grave, except that the rice produced by Dewi Sri's body grows on wet fields (sawah), while that from Tisnawati's grave needed dry fields (ladang, gogo) (compare Van der Horst van Doorn 1929:127). Indeed, Kats (1916: 183) writes that Tisnawati and Dewi Sri originally were the same figure.

A final example of the stories about rice is the Sundanese tale of Lutung Kasarung, the clothed monkey. ${ }^{14}$ Here Purbasari, the youngest and most favored princess at court is disfigured by Purbararang, her evil, jealous older sister. Purbasari then retreats to a forest hermitage. Alternately Purbararang sent her to the forest to be killed by a woodsman, who took pity on her and built her a small hut where he left her (Van der Horst van Doorn 1929:12-14). In the course of time Guru Minda, the son of the god Sang Hyang Tunggal, comes to earth in the guise of a black monkey to find a young bride who looks like his mother, the rice-mother. Guru Minda, in his monkey guise, is captured to be served at the king's breakfast, but when 'the monkey' cannot be killed Purbararang takes it for a pet. The monkey turns out to be a real nuisance, however, causing Purbararang to send it to Purbasari. There, using its heavenly connections, the monkey has a palace built for Purbasari. Purbararang sets all kinds of impossible tasks for Purbasari to complete, all of which are accomplished through the aid of the monkey and his mother, including bringing rice cultivation to earth. Purbararang, growing more and more frustrated, sets a final challenge: it is to be decided which of them is the most beautiful and has the most handsome husband. At this the monkey reveals himself to be the heavenly Prince Guru Minda, and he and Purbasari ascend to the throne.

In brief, in the first tales related above, the original action, which receives most attention, takes place in the realm of the gods (kahyangan; Zoetmulder 1982-1:660-661) or between it and a place 'in the middle of the ocean'(Rassers 1959:14), which I assume to be the underworld. It is only when the actions begin to directly affect Tisnawati or Dewi Sri that the earth and an earthly kingdom become a factor in the search for Tisnawati's desired food and the subsequent pursuit of Dewi Sri by the lustful Kalagumarang, which indirectly led to Tisnawati's death and burial in a clearing in the forest.

13. Sri is said to bring food, while Sedana represents worldly goods (dunya). In West Java in 1970, money was regarded as having male attributes. Thus money might be called kasep (handsome), a nickname for boys, while rice was referred to as geulis (pretty), a common term of address for girls (Wessing 1978:100-101). At the time informants explained that money and rice had to be kept separate, and rice could not be sold for money. Much has changed since then.

14. See Pleyte (1910); Hidding (1929); Eringa (1949); Knappert (1977: 88-98); Van Zanten (2016: 430ff.). 
Similarly, in the tale Mahapunggung, Dewi Sri was exiled from the palace to the forest for disobeying her father's orders. In one version of the story, her brother Sedana had fled into the forest for similar reasons (Kats 1916:183). Together the two decided to start a settlement, which would have required them to clear a suitable portion of the forest. Dewi Sri brings in some essential supplies and the founding couple, whom she met while roaming the forest. Then the story ends.

Finally in the tale Lutung Kasarung the princess, having been disfigured, ${ }^{15}$ leaves the palace for the forest and eventually returns to the palace. In the process she links up with the rice-mother (thus becoming the rice-daughter), uniting with the forces of fertility, which qualifies her to be queen alongside the king, the rice-mother's son, whose main responsibility is the welfare of the realm as expressed through the abundance of the harvest. In the next section, the roles of the kahyangan and the palace are much reduced, and the focus is more directly on the forest and ordinary villagers, though there is, of course, always the potential that the hero will found a princely line.

\section{The Adventures of the Rice-Spirit}

The Javanese story of Jaka Tarub and Nawang Wulan (Knappert 1977:3537; Widyamanta 1963:67-72) has many local variants in which the names of the protagonists differ as well. ${ }^{16}$ The tale opens by introducing a young village man, Jaka Tarub, whose antecedents vary. According to Knappert his mother was exiled to the forest because she became pregnant after having been seduced at a pool in the forest. There she gives birth and dies. In Widyamanta's version, Jaka Tarub's mother is Rasawulan, the daughter of the Bupati (regent) of Tuban, who refuses to obey her parents and marry, preferring, like Dewi Sri, to flee into the forest. While bathing at a spring there, she is seen by Seh Maulana, an Arab religious leader. His gaze, which she feels as in a dream, causes her to become pregnant. She searches for and finds the man of her dream, after which she gives birth to a boy and dies.

In both versions a widow at the hermitage of Tarub raises the baby, who grows up to be a handsome lad who likes to roam the forest. There one day he spies some widadari (nymphs) bathing at a pool. ${ }^{17}$ Curious, he hides one of

15. For a princess, being disfigured is a deviation from the social norm, as is remaining an unmarried virgin like was preferred by Dewi Sri (cf. Wessing 2016:373).

16. Thus Madurese versions speak of Aryo Menak and Tunjung Wulan (Lotus Moon; Robson and Wibisono 2002: 768, 816; Hatib Ws [1963]; Zulkarnaen [1987]) while in a Balinese version the nymph is called Supraba and the male protagonist is left unnamed (Sagimun [1963b]).

17. In a Balinese version (Sagimun 1963b: 107), the young man creates a beautiful garden with a pool, which then attracts the widadari. In a sense this is implied in the Madurese version as well, where the pool in which the young man discovers the widadari bathing is located in a beautiful taman sari (palace garden) (Zulkarnaen 1987). Hatib Ws. even mentions a historical spot called Taman Sarasida located in 
their garments, which they need to fly back to their kahyangan home. When the widadari must dress to leave, the youngest among them, Nawang Wulan, is stranded because her garment is gone. ${ }^{18}$ Jaka Tarub convinces her to return home with him, where he marries her. She then becomes pregnant and gives birth to a daughter variously known as Lara Kasihan or Nawang Sih.

With the presence of Nawang Wulan, Jaka Tarub's household flourishes: one grain of rice suffices to fill the rice-steamer (kukusan), ${ }^{19}$ causing Jaka Tarub's granaries to be filled to overflowing. The food, especially the rice, is also exceptionally tasty (Zulkarnaen 1987). Nawang Wulan has one rule, however: her husband is under no circumstance ever to open the rice-steamer, a rule that is also found in the Sulanjana narration. One day Nawang Wulan has to go to the river, leaving her husband in charge of the cooking fire. Curious, he peeks in the steamer, seeing but a single grain. When Nawang Wulan returns she checks the rice, and finds it not yet done: the magic has gone. Since then she has to cook rice like anyone else, causing the supplies to dwindle. When the granary is nearly empty she finds the widadari garment that Jaka Tarub has hidden there. She then returns home to the kahyangan where according to some versions she is welcomed and in another version is rejected for having become human. In the latter version she then heads to the sea south of Java, where she incarnates as Nyai Rara Kidul, the Queen of the Southern Ocean (Widyamanta 1963:69).

One significant difference between the tales focusing on the rice goddess and those relating the adventures of the rice spirit, is that the former tell of the coming into being of rice, while in the latter rice fields, both wet and dry, already seem to exist (Hatib Ws 1963:56; Zulkarnaen 1987:35; compare Sagimun 1963b: 113). Instead, the story speaks of a relationship between the rice-spirit and a village man, albeit occasionally with the potential to become a ruler. ${ }^{20}$ While rice, therefore, is already known, the nymph that the hero brings home seems to enhance the fertility of his fields: his granaries are filled to overflowing (see also Maxwell 1881: 6). Finally, in these tales, once again, the significant encounter between the hero and a nymph takes place at a pool or spring in the forest, both as the scene of the hero's own romantic encounter with Nawang Wulan, and as the location of his mother's seduction, although in one version of the story (Sagimun 1963b), the pool and the flowers are perhaps a reflection of the forest, much like the taman sari at the courts of Java

Sampang (Madura). Taman sari were a standard feature of royal residences, places where the ladies of the court could bathe, unobserved by the common gaze. These were often likened to heavenly gardens, inhabited by nymphs (Wessing 1988:173, 175; 1991:9; 2003:226-232). Compare Dewi Sri bathing in a garden of Banjaran Sari.

18. This is a common theme in Javanese tales (Hiding 1929:45).

19. See Tambiah (1970: 352) for a Thai parallel.

20. Thus Zulkarnaen (1987:35) writes that Aryo Menak was just, generous with his crops, and cared for his workers and the needy, all ideal attributes of a ruler. 
and Aceh are. At this point I shall leave the rice-spirit for the time being and consider some other apparently human maidens found living in a clearing in the forest or emerging from a bamboo there.

\section{The Maiden in the Forest: Panji Laras ${ }^{21}$}

In the story Panji Laras or Panji Kelaras, a never-do-well prince is expelled from the royal palace for excessive cock fighting and gambling. As he roams through the forest he happens upon a clearing where a maiden lives, all alone. The Sagimun (1963a) version of the tale offers no further explanation of why she lives there, or who her antecedents are.

In the East Javanese version (Van der Horst van Doorn 1929) the girl's name is Mukiningsih, who was magically conceived by a barren old woman. The sorcerer who performed the magic tried to claim Mukiningsih when she was grown, but she fled into the forest where she is eventually found by a prince (not a gambler like the one in Sagimun's version) who marries her on the spot. Having married without parental consent, the couple happily settle in the clearing where, as will happen, the maiden becomes pregnant. All this is noticed by a jealous demon who, one day when the prince is absent, attempts to kill Mukiningsih and take her place. Left for dead in a ravine, Mukiningsih is rescued by seven widadaris who build her a hut in the forest to live in. Her unsuspecting prince in the meantime lives in their home with the demonbride, who looks exactly like Mukiningsih. In due course the real Mukiningsih gives birth to a boy whom she calls Panji Laras. After some time the prince is found by the people of the court, who take him and his demon-wife home to the palace.

In both versions, Panji Laras acquires a magical, unbeatable fighting cock, which, moreover, can speak like a human being. When he grows up Panji Laras asks his mother about his father, and is told that it is the cock-fighting prince, who in Sagimun's version has in the meantime succeeded to the throne. At that the boy packs up his rooster and heads for the city to challenge the king's champion bird. Having won, Panji Laras' rooster crows and proclaims Panji Laras identity: he is the king's (or prince's) own son. The king's men follow Panji Laras home, and all is revealed. In Sagimun's version the king recognizes the wife he has abandoned and, love rekindled, he takes her and her son home to the palace. In Van der Horst van Doorn's telling, the demon-wife is killed and Mukiningsih and Panji Laras are installed in the palace.

Alternately, in a tale from the Yogyakarta area (Proyek Penelitian 1981:28-29), a girl becomes pregnant having held a magical knife on the lap.

21. According to Sagimun (1963a) this story originated in Banten (West Java), which is confirmed by the list of publications on the back cover of Zulkarnaen (1987). Van der Horst van Doorn (1929), on the other hand, writes that the story takes place in Dadapan. The Atlas van Tropisch Nederland lists several East Javanese places called Dadapan, though the locations of these are rather vague. See note 8. 
Embarrassed, she leaves her home and wanders into a faraway village. There she gives birth, not to a child but to a large egg which she places on the ground and covers with a large clay vessel (jembangan). From this egg hatches a snake. After the snake is grown it asks its mother where his father is. Told who this is the snake sets out to find him. His father, however, demands proof and, cheating, turns the snake into a magical spear.

Finally, in two Madurese stories (Sutarto, Marwoto, and Saputra 2010) a princess from Jepara in Central Java finds herself pregnant out of wedlock. She is placed on a raft which eventually beaches on a small hill in the middle of the sea, which expands to become the island of Madura. The princess gives birth to a son, Raden Segara (Prince of the Sea), in one version before, and in the other after the raft has beached. As Raden Segara grows up he develops sekti (magical) powers. Spotting two fire-breathing dragons on the beach, he defeats them and turns them into magical spears. After this he asks his mother who his father is. In answer she tells him to stand back to back with her. Then she suddenly disappears into the Laut Selatan, which in this case is either the Indian Ocean or the sea south of Madura. In the other version Raden Segara marries a girl from the Laut Selatan, which could be a reference to Nyai Rara Kidul.

To summarize, in the Panji Laras stories we have a maiden living in the forest as focal figure. A young man arrives, this time a prince, and they fall in love resulting in her pregnancy. Then developments whisk the prince away on a side-track. In the alternate tales from Central Java and Madura the girl's strange position results from an exile to unfamiliar, possibly dangerous places, namely a far-away village and a raft out at sea. The danger in strange locations lies in the girl's unfamiliarity with local customs and the eccentricities of the local tutelary spirit (cf. Pemberton 1994:237; Wessing 2017: 524), while the danger posed by a raft out at sea, crewed solely by a pregnant princess need not be expanded on. In both, therefore, the danger lies in the unfamiliarity and thus unpredictability of the place of exile. In a final example we find the maiden once more in the forest, but this time locked away in a wondrous bamboo.

\section{The Maiden in the Bamboo}

In a version of the tale of Rama and Sita told in Malaysia and Java (Zieseniss 1963, Anonymous 1953), the action opens when king Dasaratha decides to have a new capital city built. ${ }^{22}$ His men begin to clear a suitable spot in the forest, where they come upon a large clump of golden-hued bamboo, growing on a hill in the middle of their clearing. Try as they may, they cannot fell this bamboo, which they report to king Dasaratha. The king himself takes a hand, and with one blow fells the bamboo, out of which then appears the beautiful

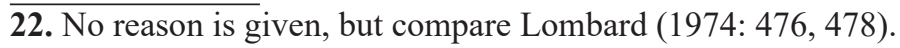


maiden Mandu dari, much like Tisnawati appeared out of a jewel-case in the Mengukuhan story. The king takes Mandu dari to his palace in the new city Mandura puri negara. He marries her, she eventually becomes pregnant and gives birth to prince Rama.

In the meantime, the demon Rahwana has become aware of the beautiful Mandu dari and desires her for himself. Owing to various machinations, she is forced to consent, but slyly manages to clone herself using some dirt from her skin (daki). The clone is called Mandu daki. King Dasaratha then has sexual relations with Mandu daki before Rahwana can do so, resulting in Mandu daki's pregnancy with Sita. Later Rama marries Sita and the conflicts described in the Ramayana ensue.

Two variants of this story are reported by Proyek Penelitian (1978) and Hervey (1882) ${ }^{23}$ In the former a childless old couple dream they should follow their dogs into the forest and to overnight where the dogs stop. At the place indicated by their dogs they find a wondrous clump of golden hued bamboo. When they cut it down a magical baby girl emerges, which they take home. They receive supernatural instructions about the baby's care and preparation for an eventual marriage with a mighty king. The story related by Hervey tells how the Khatib (Islamic preacher) Malim Seleman, a descendant of Alexander the Great, pursuing a beautiful princess, falls asleep in the forest beneath a very large bamboo. During the night the princess appears to him in a dream, but she disappears at dawn, after telling him he will find her in the bamboo. In the morning he attempts to fell the bamboo using various tools, finally succeeding with a kacip (scissors for cutting betel nuts): the princess tumbles out of it, they marry, and ride off to Bukit Peraja where they disappear. Both are said to live there invisibly till today, and their horses, in full trappings, may occasionally be seen.

In brief, in this tale the maiden, here a princess, emerges from a magical clump of bamboo in a clearing in the forest. This maiden directly and indirectly gives birth to Rama and Sita, the future ruler and his consort who is in turn associated with rice, as is clear from the stories dealing with the rice goddess. ${ }^{24}$ In this connection it is interesting to briefly look at an Indian tale from Mandla (Mahdya Pradesh) relating the origin of rice (Fuchs 1960: 422). This tale speaks of a time when humans did not yet have rice. The only one who has grain is Janki mata ${ }^{25}$, also known as king Rama's wife Sita. Janki

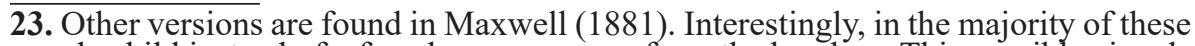
a male child instead of a female one emerges from the bamboo. This possibly signals a change in orientation toward Islam.

24. Since as a clone Mandu daki is nearly identical with Mandu dari, Rama and Sita, the offspring of King Dasaratha's relations with the two, could almost be siblings, much like Sri and Sedana were in the story of Mengukuhan.

25. Janki mata is an incarnation of the goddess Sita: https://en.wikipedia.org/wiki/ Janaki_Mandir. 
mata has six fingers on one of her hands, so she cuts off the sixth one and sticks it into the ground. After some time a bamboo grows from the cutting, with many sections filled with all kinds of seeds. One day a domestic pig finds the bamboo and bites a hole in it out of which streams grain. It eats its fill and then returns to its sty, where the next day its owner, Chandu Domar, spots the grain in the pig's feces. Chandu Domar follows the pig's tracks back to the bamboo, ${ }^{26}$ which he then opens further, exposing the grain inside which he then takes home. There is enough grain for the whole village, and everyone's granary is filled to overflowing. ${ }^{27}$

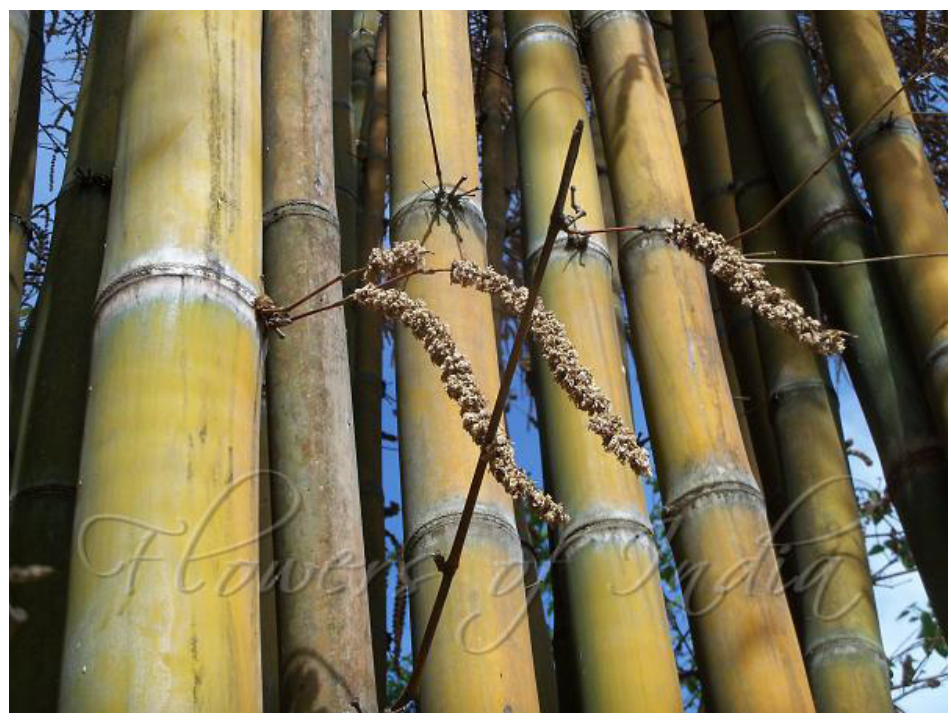

Fig. 1. Flowering bamboo (bambu betong; Dendrocalamus asper). Image courtesy of Flowers of India (https://www.flowersofindia.net/) and reproduced with permission.

This story highlights the connection between Sita and bamboo although, rather than, as in the Ramayana tale earlier, Sita emerging from a bamboo, or more accurately from a bamboo-maiden, the grain-containing bamboo is an integral part of Sita's (or Janki mata's) body. This clearly links Sita and grain, just like Dewi Sri and the rice-spirit we considered above. This link is further highlighted in the story told by Hervey (1882) in which the khatib finally opens the magical bamboo using a kachip (also kacip), a betel-nut scissors,

26. Mabuchi (1954:25) relates a tale from Taiwan in which a man from heaven planted gourds and three kinds of bamboo. From the bamboos emerged the pig, millet, and glutinous rice, while ordinary rice came out of the gourd, once more linking bamboo, rice and pigs.

27. Fuchs (1960: 68) writes that bamboo seed is a much relished food. 


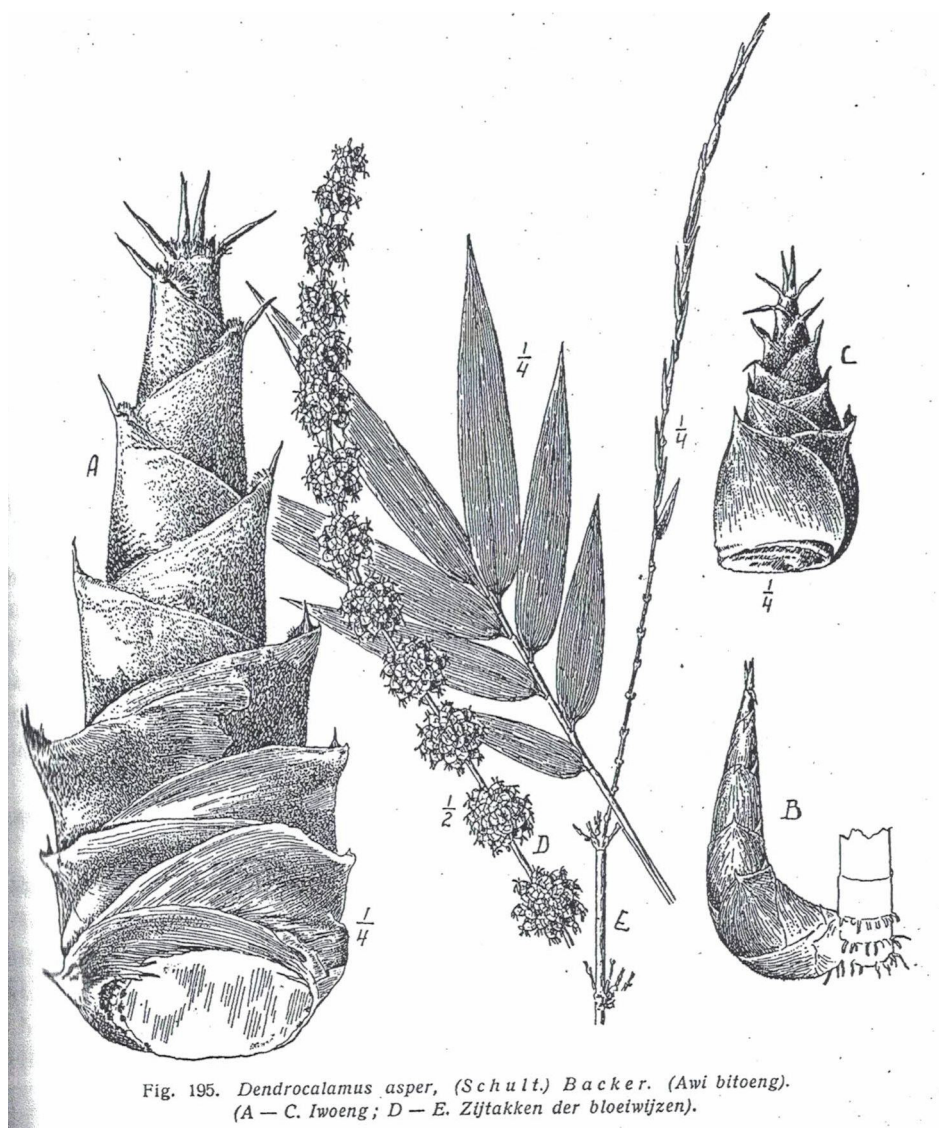

Fig. 2. Botanical drawing of bamboo betong (Dendrocalamus asper) (Ochse 1931:309).

betel nut and sirih (piper betle; Seno-Sastroamidjojo 1962: 322) leaf quid being part of traditional offerings to the rice goddess Sri (Purwadi 2004:137; Wessing 1978: 119; 1999: 652). ${ }^{28}$ Finally, Sita is the wife of king Rama, who in turn is an incarnation of the god Vishnu (Dowson 1972: 256), logically making Sita an incarnation of the rice goddess (see also Wessing 1978: 112).

28. A kacip is a betel nut scissors, finer examples of which are often decorated with swastika symbols. Jessup (1990: 168, 243-244) identifies the swastika as a sun symbol, but elsewhere (Wessing 1986b: 56) they are seen as a version of the double spiral, a symbol of continuity linking the unborn with the ancestors, the underworld and the sky, and Sri and the ruler. The betel nut which is cut or crushed with this tool, is part of the traditional sirih offering to the rice goddess. Note the homophony between Sri and sirih. Thus, the kacip and its symbols are linked with the rice goddess and with the bamboo from which in the Indian tale the grains originate. 


\section{A Local Expression of the Tales}

All this neatly comes together in a ritual song, Adulilang, ${ }^{29}$ recorded by $\mathrm{Mr}$. Randal Baier in the village Ciptagelar in the Banten Kidul area of West Java. This song, which is accompanied by an angklung (tuned, shaken bamboo rattles) ensemble, and the context of its performance, touch upon a number of elements that were present in several of the stories discussed so far. It is played and sung at the full moon, reminding us of the nymph Nawang Wulan Sasih (Nawang of the full moon), who in the story of Sulanjana was the wife of the king of Pajajaran. As explained by Aki Dai, the adat elder (leader and judge in matters of custom) of Ciptagelar, the song is also performed at such ritual occasions as greeting the newly harvested rice, its being placed in the granary, its first husking, and its first consumption. The song relates how a person suddenly came upon a beautiful maiden, walking along a quiet path along a stream or in the forest. Not having seen her for a long time, the narrator had longed for her and seeing her, is pleasantly surprised. The maiden is referred to as kekasih (beloved).

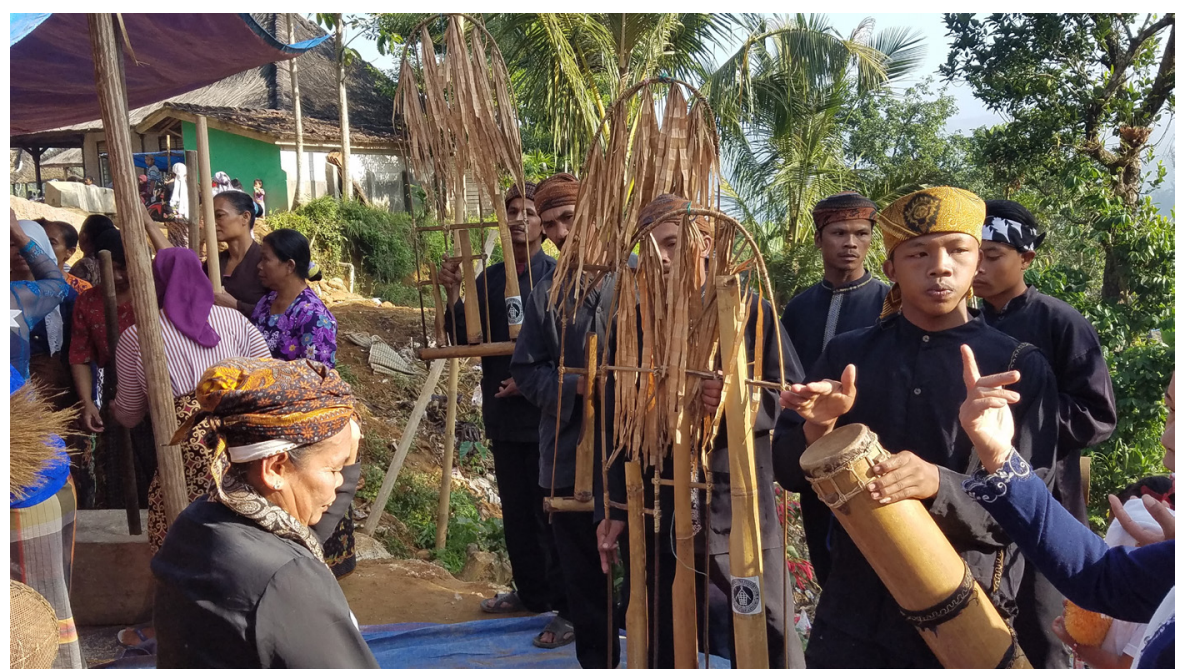

Fig. 3. Angklung instruments. Note that the bamboo's flowers in figure 1 and the decorations on the angklung seem to evoke the rice stalk rather than literally depicting it. (Photo: Randal Baier).

29. Probably Aduh Ilang which can be freely translated as Alas, how I have missed you. The song and the associated ethnographic material were collected between 2013 and 2018 by Mr. Randal E. Baier, M.A., ethnomusicologist and Arts and Media librarian at Eastern Michigan University, Ypsilanti, Michigan. I thank him for generously allowing me to use his observations here. For more information on the village Ciptagelar see https:/www.google.com/maps/place/Kasepuhan+Adat+Ciptagelar/@$6.8029236,106.4978655,379 \mathrm{~m} / \mathrm{data}=! 3 \mathrm{~m} 1 ! 1 \mathrm{e} 3 ! 4 \mathrm{~m} 5 ! 3 \mathrm{~m} 4 ! 1 \mathrm{~s} 0 \times 2 \mathrm{e} 427 \mathrm{fd} 7 \mathrm{e} 95 \mathrm{e} 48 \mathrm{dd}: 0$ x26bc5cb0766c1524!8m2!3d-6.8026891!4d106.4982992 
While on the face of it, this could refer to any pretty girl one hasn't seen for a while, the association of its performance with the newly harvested rice and the full moon clearly point toward the beautiful rice-spirit (Sundanese: geulis, pretty one) who in the narratives was time and again found wandering in a forest or bathing in a pool there. The associated angklung accompaniment, favored by the rice-spirit (Baier 1985:9; Garna 1988: 323-325), strengthens this conclusion. One striking feature of these bamboo instruments is a decoration that seems to emerge from the top of the bamboo. ${ }^{30}$ This decoration resembles bundles of grain, streaming down and swaying ${ }^{31}$ as the instrument is played (see figure 3), reminiscent of the grain that emerged from bamboo in the Mandla tale, in which bamboo is closely associated with Sita and rice. ${ }^{32}$ Furthermore, in the Ramayana version of the princess from bamboo story, Rama's queen Sita is the daughter of a clone of the maiden that emerged from a miraculous bamboo, once more equating the rice-spirit, bamboo, and the rice itself. The khatib Malim Seleman's (Hervey 1882) use of a kacip (betelscissors) to open his bamboo also makes this connection.

To summarize, all the stories considered here involve a relationship with a maiden in a clearing in the forest, and thus indirectly also a relationship between the maiden and the forest-clearing itself. Sometimes, as in the stories dealing with the rice-goddess, she is buried there after being sexually violated or, in the case of Dewi Sri, fleeing from a misalliance. In other stories she is a bathing nymph or just a young woman, sometimes a princess, who for some unexplained reason lives in the clearing or is contained in a bamboo located there, perhaps waiting to be found by the hero. The question that arises then concerns the nature of the relationship between the maiden and the forestclearing. Before this can be answered, however, the identity of the maiden herself must be clarified.

\section{The Maiden and the Forest}

To start with the various stories about rice, these all concern spirit beings responsible for the introduction or the welfare of rice. In the Sundanese tale of Sulanjana these were referred to as pohaci or Dewi (goddesses), while in the

30. Mr. Baier informs me that this is a common decoration on angklung in West Java. See Baier (1986).

31. Ayun-ayunan, rocking, swaying, said of rice standing in the field and struck by the wind. This movement is made by the women attending the performance of the song. While there are differences between individual varieties of bamboo, their flowers are quite similar. See for instance the botanical drawings in Ochse (1931: 309, 319, 324, $325)$.

32. Elsewhere in West Java a ritual leader actually places rice grains in a bamboo in which he has cut five holes. This is accompanied by angklung music, dancing and singing (ASS 1990:34; see also Hefner 1985:122-124 for the Tengger area of Central Java). 
Central and East Javanese tales they are commonly called widadaris. ${ }^{33}$ The difference between them is not always clear. Coolsma (1911:490) defines pohaci as female beings of heavenly origin, also goddesses, to which Hardjadibrata (2003:643) adds faerie. Widadaris on the other hand were originally an Indian spirit (Skt. widyādhari; Zoetmulder 1982-II:2264), a kind of fairy living in the Himalayas. In Java and Bali this idea was adapted, the widadaris becoming seven solely female spirits, like the Sundanese pohaci especially associated with rice. Thus in a Balinese reading of the story of Jaka Tarub and Nawang Wulan (Sagimun 1963b: 110), the nymph is called Supraba or Sukurma, who is synonymous with rice (Pigeaud 1968:269; Soebardi 1975:138). Supraba is there said to have seven signs, seven indeed being the number of widadaris that Pigeaud mentions, of whom Supraba is said to be the youngest.

Pohaci and widadari, then, are readily equated with rice (Satjadibrata 1954: 313; Panitia Kamus 1980:391). Dewi also being an India-derived concept, it would be tempting to link dewi and widadari with greater Indian influence, and the pohaci with less Indianization. This is difficult, however, because at least in modern Indonesian, words like widadari and dewi have become part of the general vocabulary, and do not or no longer reflect degrees of Indianization.

One clue is offered by some of the tales themselves. Thus, Kats (1916: 186-187) writes that while being chased by Kalagumarang, Dewi Sri suddenly disappeared. On the spot where she was last seen the same plants begin to grow that appeared from Tisnawati's grave. Dewi Sri's rice, however, had to be planted on flooded fields (sawah), while Tisnawati's could grow on dry fields (ladang, huma, or gogo) (compare Hidding 1929:11; Van der Horst van Doorn 1929:127). ${ }^{34}$ If, indeed, rice planted on ladang preceded sawah agriculture (see e.g. Pleyte 1910: xviii-xxiii), the concept of pohaci would have preceded that of dewi and widadari in Java. However that may be, in the literature pohaci and widadari or dewi were apparently considered identical (Hidding 1929:39; Kats 1916:183, 188).

The rice-spirit's position as either the origin of rice or the enhancer of its productivity, which we saw in the Nawang Wulan stories, emphasizes her role as a spirit or goddess of fertility, to which Kats (1916: 188) adds the ideas of happiness and welfare, which in an economy based on rice agriculture would

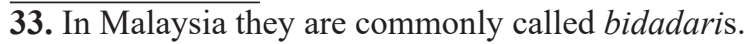

34. For a Thai account of the origin of wet and dry rice agriculture see Tambiah (1970: 352). It is possible that the Central Javanese courts had better developed irrigation systems than those in East and West Java did, along with the technical and bureaucratic expertise needed to administer such systems (see Holtzappel 1986: 843), though such differences would in any case only have been relative. Sundanese rulers from earliest times were reputed to have created large scale irrigation systems (Wessing 2011: 330). In relatively much drier East Java, gogo or ladang (dry-field) rice agriculture was a significant factor in Majapahit's economy (Holtzappel 1986: 237).
} 
go hand in hand. As we saw earlier, as Sri she is the wife or sekti (female creative energy; Dowson 1972:274; Stutley and Stutley 1977:260) of the God Vishnu, and together they readily incarnate as the ruler and his wife. In fact, this was also clear in the Sri Mahapunggung tale, in which Sri and Sedana (= Vishnu) seem to form an inseparable duo (Kats 1916: 189). Thus, as queen the maiden is the embodiment of the creative powers of the rice-spirit.

Another expression of these formative or creative powers is found in the Panji Laras and the Rama and Sita tales, where she is the generative force behind the rise of a prince to the throne (see Wessing 1990:239). Here, like the exiled Dewi Sri and the rejected Purbasari, she lives alone in a clearing in the forest, removed from human society. Then a prince or a king arrives and intrudes on her life. This intruder is undergoing a transition: Panji Laras has been exiled to mend his ways, while King Dasaratha is in the process of building a new capital city, which is equivalent to a cosmic realignment of the kingdom. ${ }^{35}$ In other words, both the prince or the king and the maiden are in a transitional or liminal state during which they discover each other, and either immediately have sexual relations or wait until the maiden is conveyed to either the palace (King Dasaratha) or a village where she is 'married' (Jaka Tarub).

We should be cautious about the idea of marriage, however, as many of these tales are translations, which are bound by the vocabularies of the target language, as well as social sensitivities of the time. ${ }^{36}$ The Indonesian, Javanese and Sundanese languages have several words for marriage, namely the polite Islam-based menikah, and the refined Javanese krama and rabi (Sund. rarabi, mirabi) all of which usually involve religious and/or civil functionaries. In addition there is also the word kawin, which in Javanese and Sundanese is considered rude or ordinary, and not suitable for discussing e.g. royal marriages. ${ }^{37}$ It is, however, not uncommon (cf. Sagimun 1963a:167;

35. As Heine Geldern $(1930,1942)$ pointed out, the Indianized state ideally had to be an image or reflection of the cosmos, in which the king's throne was coordinate with Indra's throne on Mount Meru. The more perfect the alignment, the greater the benefit derived.

36. Hidding (1929:39) uses the Dutch gehuwd met (married to) to discuss the relationship of the king of Pajajaran with the rice goddess. Elsewhere (1929:45) he uses trouwen (to marry) for the relationship between Nawang Sasih and her young man. Here Zulkarnaen (1987: 35) uses the Islamic menikah, perhaps unavoidably since it has become part of the modern Indonesian language. Various other tales (Proyek Penelitian 1981: 28; Widyatmanta 1963:67; Van der Horst van Doorn 1929: 12) avoid the word marriage altogether and speak of jodoh (match or mate), diperisteri and tot zijn vrouw maken, which both mean 'to take as wife', even in contexts like Panji Laras' clearing in the forest where civil registry or clergy were conspicuously absent. Other authors simply write that the couple spent the night together (Hervey 1882:1034), or just state that the girl was pregnant (Sutarto, Marwoto and Saputra 2010).

37. It is classed as kasar, or ngoko, which is usually translated as rude as opposed to the more halus or lemes (refined) krama or rabi (Robson and Wibisono 2002: 396, 
Hatib WS 1963:56). One problem with this word kawin is that it can also be used to speak of the breeding of animals or of simple human copulation, which is e.g. what befell Tisnawati, and is at least implied in a number of the tales in which the maiden coupled with the prince or the youth without even a mention of clergy or civil bureaucracy (e.g. Hervey 1882:103-4; Sagimun (1963a). The sex in these cases can therefore be said to be irregular, which may be the point of the whole affair because, as Smith and Woodward (2016) discuss, sexual congress with a 'magical woman' is often a path to power, especially it seems, when such intercourse is irregular (cf. Gottowik 2018). ${ }^{38}$ Thus Ken Anrok's conquest of Ken Dedes was accompanied by deceit and betrayal (Knappert 1977: 7-9; Smith and Woodward 2016:324), while prior to Senapati's founding the realm of Mataram, he enjoyed three days and nights of passion with the Queen of the Southern Ocean, Nyai Rara Kidul, in her under-water palace (Olthof 1987: 80-83) ${ }^{39}$ Women, Smith and Woodward write, are seen as points of access to spiritual powers through sexual relations, which we see realized here through his contact with the maiden in the forest, the source of power and fertility.

Especially important for aspiring rulers or village founders, then, was a relationship with a tutelary spirit, localized at a forest shrine, often in a grove of trees located at the edge of the community or at the boundary of the state (Wessing 1990; 1999; Wessing and Barendregt 2005; Falk 1973: 3; Schnepel 1995: 148$)^{40}$. This tutelary spirit, always female and in India cast as tribal

$512,610)$. For reasons that would take us too far afield, I prefer a classification of common or ordinary when discussing non-refined language. Cf. Wessing 1974.

38. Sexual behavior can be seen as a form of rebutan, struggles, even violent ones, to obtain ritually powerful objects (Robson and Wibisono 2002: 620; see Pemberton 1994: passim). This would be true of both irregular and sanctioned sex on e.g. the wedding night, at least as idealized by the court poets (pujangga) (see Creese 2004: 172-178). See also Shulman (1980:119-120, 128), who relates a South Indian (Tamil) myth, the central motif of which is 'the revelation of the deity through violence done to his symbol', here his linga, leading to '...its desired result, the fertility rooted in violence'.

39. Access to fertility through irregular sexual intercourse is not restricted to royalty, but is also seen as a path to increased spiritual power or prosperity by ordinary people. There are well-known locations to which spiritual power (kasekten; Anderson 1972) is attributed, where sexual intercourse with a person not one's spouse is practiced for just this reason, married couples sometimes splitting up to each find his or her sexual partner (Gottowik 2018; Smith and Woodward 2016: 318 ; Sentot Js 1990:28-9, 60-61; see also the essay by Monteanni 2018, published on-line in Palm Wine). Also, farmers in several places in Southeast Asia would (in the past?) copulate in their fields, or place images of copulating couples or sexual organs there, in order to bring rain and thus enhance the fertility of their fields (Wilken 1912:41; Wessing 1997: 342, note 38; see figure 4).

40. Parang Kusuma, the location where the sexual union of Panembahan Senapati, the founder of Mataram, and Nyai Rara Kidul, the Queen of the Southern Ocean is commemorated, often through irregular sexual activities (cf. Gottowik 2018: 398), is a beach community that lies on the boundary between the Javanese realm of Mataram and the Queen's under-water realm. 


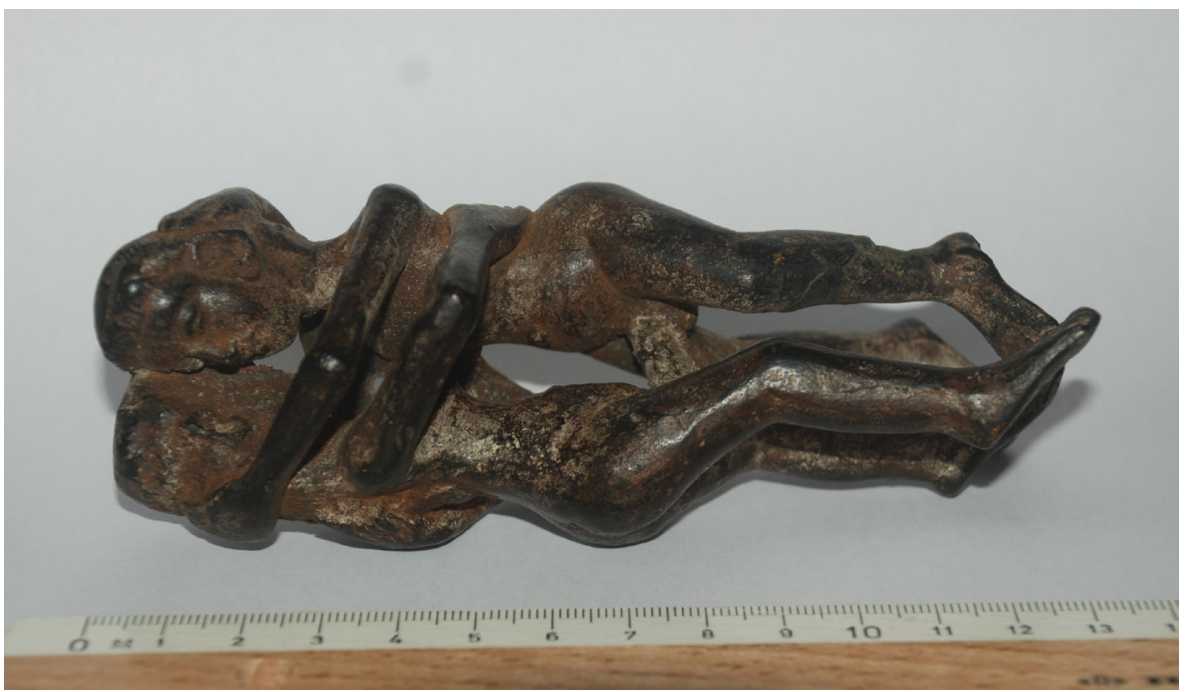

Fig. 4. Image of a copulating couple. Bronze. Purchased in Bali in 1991. (Photo: Steve Wessing).

mother or earth goddess (Schnepel 1995:147-8; Woodroffe 1975:17), was the 'metamorphosis' of a wild forest spirit (Domenig 2014: 35) that now acted as the guardian of the realm and its welfare, i.e. its fertility. At the state level this relationship was often cast as a marriage between the king and the spirit, in which the sexual aspect received special emphasis (Hara 1973). Sexual congress with the spirit could be dangerous for the unqualified (cf. Shulman 1980:122-3), but if successful her female powers of fertility would unite with those of the prince or king, greatly enhancing his cosmic potential. ${ }^{41}$ Smith and Woodward (2016: 320-5) indeed consider sexuality 'a fundamental dimension of the acquisition of magico-spiritual power in Java'. The tutelary spirit then, variously in the guise of the rice-spirit or the attractive maiden in a forest clearing, was the source of the king's female creative power, his Sakti (Jav. kasekten) ${ }^{42}$ and thus his suitability to rule (compare Schnepel 1995;

41. The king's cosmic potential was ritually concentrated at the center, his palace, through a circumambulation or by ploughing a furrow around the capital (Paranavitana 1970: 31-2; Heine Geldern 1942:17). The sexual aspect of this ritual ploughing, which in effect created a vulva around the center, is clearly illustrated in Danasasmita et al. (1977, II; 203-205) in which a man's penis is used as a ploughshare. The Babad Tanah Jawi, finally, reports how upon his death, king Mangkurat's penis became erect and emitted a glow. Pangeran Puger noticed this and quickly sucked up the glow, causing the erection to subside. This act transferred king Mangkurat's kasekten to Pangeran Puger, and led to Pangeran Puger being designated as king Mangkurat's successor (Olthof 1987: 268).

42. In Sanskrit śakti denotes 'power, ability, strength, might, regal power, energy or active power of a deity personified as his wife (Zoetmulder 1982, 2:1607). For modern Javanese Anderson (1972: 7) characterizes kasekten as that 'intangible, mysterious, 
Barendregt and Wessing 2008: 556). As we saw in the tales, she easily equates with the queen.

Having examined the maiden in her various guises, there remains the question of her relationship with the forest and the clearing in which she is found: she variously lives there, bathes there, flees there to safety, and is buried there. In the stories we consistently found the sequence maiden-clearing(bamboo)-forest, in which the spirit seemed to be an aspect of the forest itself; they are part of the same symbolic category. ${ }^{43}$ This is made clearer if we look at one of the names by which the earth is known in West Java, namely Nyimas Bumi Siti Pertiwi (Skr. Prthivi), ${ }^{44}$ which corresponds to Indian usage (Dowson 1972:243). Kinsley (1986: 8-9) points out the goddess Prthivi's maternal and fertility aspects, calling her, like the rice-spirit, 'the source of all plants, especially crops, ... [who] nourishes all creatures that live upon her.' She is the sustaining mother and equivalent to the rice-spirit and the śakti whom Woodroffe (1975:17) calls 'God as Mother'. In brief, she is at once the earth and, also, through her frequent association with water, the fertility spirit (cf. Andaya 2016), or perhaps better, the forest, the earth and the fertility spirit form a single category, and as such the maiden is a concentrated expression of the energies of the forest, the forest-as-śakti.

The maiden, furthermore, often lives in or is buried in or founds a village in a clearing in the forest, which, especially when associated with the palace, can take the form of a garden (see note 17 above). This is the location where the women of the court bathe, off limits to all but the family - or the brave. These gardens can be seen as reflecting the spirit's grove that was set aside for it as part of the original founding agreement (Wessing 1988: 171-6; 2003:223, 230-2; Domenig 2014: chapters 1 and 2; Proyek Penerbitan 1981: 38-42). In Javanese and Sundanese, clearing the forest to start a community is called mbabad, while babad also means history or chronicle. In other words, clearing the forest (Jav. mbabad), like King Dasaratha did, is to begin the history of that particular place.

In order to clear the forest, however, one must penetrate it, which once more draws the attention to the sexual aspect of the relationship. As Falk (1973: 2) writes, the aspirant king penetrates the spirit's nature, subdues her, and makes

and divine energy which animates the universe. It is manifest in every aspect of the natural world, in stones, trees, clouds, and fire, but is expressed quintessentially in the central mystery of life, the process of generation and regeneration.' In popular usage, sekti indicates having or having access to magical powers (Robson and Wibisono 2002: 661). The meaning of sekti and kasekten, therefore, can range from cosmic powers to magical ones, depending on whether it is wielded by a king or by a magician. Cf. Work (2018: 8-9).

43. This does not mean, of course, that they are always directly interchangeable. They participate in the same set of meanings and through their interaction can expand this set of meanings.

44. In Java and Malaysia this is also the meaning of bumi. 
her his wife. ${ }^{45}$ In the process, the ruler gains the cosmic powers (kasekten) needed to rule (Wessing and Barendregt 2005: 11; Winstedt 1929:460-1; 1945:135-6, 138-9; Hidding 1929:39). It is, therefore, through the penetration of the forest in the form of the maiden's hutan larangan that the aspiring ruler gains the necessary powers: he must conquer the female wilderness and bring its powers of fertility, in the form of the maiden, back to his palace.

It might be objected at this point that protagonists like e.g. Dewi Sri and Purbasari, started out as princesses before retreating to the forest and eventually returning to the palace. It must be remembered, however, that these princesses were all in some way poorly fitted to their courtly environment and the rules that governed it: Purbasari was disfigured and Dewi Sri refused to get married when she was expected to. These maidens were clearly out of place, and it was only after their retreat to the forest that their true natures became apparent. They were the rice goddess or rice-spirit, and once this was recognized they could return to the palace in a new incarnation as the consort of the ruler.

Clearly, this could not be done by just any man as there are risks associated with entering into such a relationship and bringing home the powers of the forest. To be successful, one has to be able to deal with these powers. When the peasant Jaka Tarub ventured to bring home Nawang Wulan, things appeared to go well at first, only to be spoiled when Jaka Tarub could not control his curiosity. With just one peek, the magic unraveled and the arrangement collapsed. King Dasaratha, on the other hand, successfully brought home the maiden he found in a clump of bamboo.

Thus, rather than having a strange situation of a maiden living in a clearing in a forest, we see that symbolically the three are closely related and indeed share an identity: the forest is a visible expression of the fertility of the earth (Pertiwi) and the maiden in turn embodies this fertility in human form. The clearing in which her hut, sometimes a bamboo, is located, sets her off from the main body of the forest. It is in this liminal or focused space that the prince unites with her, and by doing so he, or the offspring of their union, ${ }^{46}$ acquires

\begin{abstract}
45. One part of the traditional Sundanese wedding activities takes place in a symbolic forest garden (kebon alas), during which the bride and groom move a large pestle used to husk rice (alu) up and down in the lulumpang (mortar), simulating sexual activity. Aki Dai, Mr. Baier's informant, pointed out the parallel between sexual relations and some lines in the song Aduilang that deal with planting rice on a dry field using a dibble stick. Among the Using of East Java the first sexual penetration during the wedding night is called babad alas melebu guwa (clear the forest and enter the cave), while the woman's mons veneris is called her hutan larangan (forbidden forest, sacred grove), the home of the spirit and her powers, which is penetrated on the wedding night. Compare the flaming vulva attributed to Ken Dedes (Smith and Woodward 2016) conquest of which would make the man a king, and the snake that lived in Nyi Rara Panas' vulva, which killed her husbands at first penetration until Sech Durahman outsmarted it and turned it into a keris (ceremonial dagger) (Prawirasuganda 1964: 86).
\end{abstract}

46. E.g. Panji Laras and Rama and Sita. 
the forest's powers, especially those of fertility. This power of fertility is acquired through the agency of the forest, which in the tales had been there without being emphasized. It is made visible among other things through the maiden, or, in other contexts, the tiger, the magician (pawang), and various spirits among which the rice spirit and the tutelary or guardian spirit (Wessing 1986a; 2006a). The maiden can thus be seen as a kind of guise through which the forest is presented without itself being highlighted.

This is not to say that the forest is the only or even the ultimate source of power (kasekten), but rather that it seems to be privileged in matters of fertility, a non-material force. Kasekten is also found in or adhering to objects, among others keris (daggers), tombak (lances), swords and other weapons, certain musical instruments, and symbols of authority (Sutarto, Marwoto and Saputra 2010: 22, 43; Prawirasuganda 1964: 85-86; Maxwell 1881: 7) as well as semi-precious stones (batu akik), and especially the ruler's throne. This throne is the former stone seat of the realm's tutelary spirit, to the conquest of whom he owes his power (Wessing 2003: 222-224, 233-234). Note that many of these powerful material objects derive from the material earth and are in the rice mythology associated with the male, Sedana (Vishnu), the rice-spirit's partner and the ruler who marries his realm (Hara 1973).

We have here then a dichotomy between a female-oriented non-material force of fertility and male-oriented material objects, reminiscent of the lahirbatin (body and spirit) and wadah-isi (container and content) oppositions found in other contexts of life (Wessing 2006a: 79). This dichotomy is rooted in śakti, in India said to be nature or the earth itself (Woodroffe 1975: 87). ${ }^{47}$ Woodroffe speaks here of the worship of the female force, though this should not blind us to the fact of the necessity of the male aspect. As Ibu Fatma, a farmer's wife in East Java, once laughingly said to me in response to a question about the rice-spirit, 'you can only have fertility if both female and male are involved'.

Returning to the forest, as analysts we must be careful not to attribute agency to it (see Work 2018), even though this seems implicit in the tales and in what informants say, attributing agency either directly to the forest or to denizens within it. The reason for this is probably that in order to deal or interact with the powers of the forest, these must be socialized and preferably named, because agency presumes rationality and a degree of socialization. For instance, people in East Java speak of the Alas Purwo (Ancient or Original Forest) in easternmost Java, as being able to purposely change the paths running through it, causing incautious intruders to lose their way. Kasekten seems to be especially concentrated there. Similarly, the Tobelo of Halmahera say that the spirits inhabiting the forests, beeches, and other parts of the landscape that serve as topological markers can 'subvert the familiar

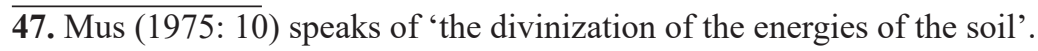


spatial order by changing the course or the current of rivers or the stellar constellations, so that the traveller traversing the forest or sailing the sea loses his way' (Platenkamp 2007:106). More generally, the Batek of Malaysia are described as having 'an intimate relationship of interdependence' with the plants, animals, and spiritual beings in their world, including the forest, with whom the people must maintain harmonious relations (Endicott 1979: 25, 53, 82 ), implying consciousness and a degree of rationality on the part of these beings. Others speak of spirits owning or occupying the forest, and being the powers of fertility within it (cf. Wessing 2006a). More elaborately, the Chewong of Malaysia (Howell 2016) see the forest as animated and populated by non-human beings that, like humans, have intentionality or agency. While these may appear to us as e.g. elephants, rocks, or plants, for some these are only guises or cloaks that hide their essential humanity. Such guises, as Emigh (1996: 29, 153) noted about masks in Bali, 'facilitate [a] ... transference of identity' and 'obscure the identity of the performer' while symbolizing the source of the power being displayed. In the various tales discussed here, the rice-spirit and the maiden seem to act as masks or cloaks that hide or obscure the identity of the forest: which through the guise appears to be the character portrayed by the disguise. As Emigh writes (1996:275), citing Peter Brook [1987: 218]), "a traditional mask is an image of a man without a mask [...] an outer casting that is a complete and sensitive reflection of the inner life". This is why our attention is drawn to the character assumed, and we lose sight of the 'silent' entity behind it, in this case the forest, the source of the power expressed by that character. Conversely, focusing intently on a particular entity can lead the observer to see behind it, revealing the source of power, here the forest.

The maiden and the rice-spirit, ${ }^{48}$ then, are ways of talking about specific aspects of the forest's and ultimately nature's powers as perceived by our narrators, as are the spirits who are cast as the owners or incarnations of the forest's power. These expressions of power can seem to continually shift shape: ${ }^{49}$ men metamorphosing as spirit-tigers, tigers seeming to be men, men turning into women (Enthoven 1914: 124), an old mystic suddenly appearing as beautiful princess (Wessing 1986a, 2016: 382), and a beautiful maiden incarnating as the rice crop and linking the kahyangan of the widadari with the human world of villages and palaces. Sometimes, as in the Indian myth of Angulimala, its denizens take on the features of the forest, blending as it were with their natural surroundings, the place where they belong. Rather than, as is often thought, being residents that are somehow nearly interchangeable with the forest (e.g. Brancaccio 1999:108-9; 116), they must be seen as differing incarnations or expressions of nature's powers as channeled through the forest.

48. And elsewhere the tiger (Wessing 1986a).

49. Or don or discard a cloak or mask. 
The forest, then, is a strange place, a riddle, the deeper meaning of which is to be discovered by those equipped to understand it, the person with the powers of kasekten who can cross the boundary between the community and the forest, i.e. the ruler (Winstedt 1945: 135-6). How one sees this depends, of course, on one's assumptions about reality, and it might be that rather than shifting shape the various entities are felt to belong to a single symbolic category, making, as an Using informant explained to me, the form taken depend on the need of the moment. As Howell (2016:58) notes, '[d]etailed explanations upon such ontologies are vital, but particularly difficult given the metaphysical chasm that exists between observer (anthropologist) and observed (people studied).'

\section{Conclusion}

Starting with some seemingly disparate tales concerning the rice-spirit and the rise to power of princes, we found a common theme in them of a maiden and her connection with the forest. Placing this focal point in the context of other narratives and information about spirits and goddesses made the nature of the forest, the maiden, and other figures stand out more clearly: they are all specific projections of the power of fertility that seems to find its primary expression in the forest, the further forms its takes depending on the needs of the ongoing narrative. While present silently and unremarked in the tales, these stories and the activities depicted in them reflect an aura of magic that suffused the forest to the Javanese and Sundanese narrators. It is a place of wonder and miracles, of transition and access to great powers (kasekten), inhabited by fabulous often malicious beings that, even when not malign, should be treated with respect and circumspection because their possibly unfamiliar customs and expectations (Schefold 1989; cf. Falk 1973: 13-4): shape-shifters, a common idea in Southeast Asia, are innately ambiguous because one can never be sure what one is facing (Wessing 1995: 204).

Much has changed in Java and Sunda in the intervening years. Even in the 17th and early 18th centuries most of Southeast Asia was still covered by majestic forests, but during the colonial era and increasingly since the end of WWII these have been generally threatened by large-scale logging and clearing for agricultural purposes (Solis 2017; Kummer and Turner 1994; Lombard 1974: 474-476). Not much of them remains, and rather than as warily respected places of awe and wonder the remnant forests are now often depicted as horrible, dangerous places suffused by supernatural powers, best avoided (Harimurti 2017: 2) ${ }^{50}$. This has not lessened with the disappearance of the actual forests, which is not always generally acknowledged anyway: the forests are there, some unspecified distance away, and the path through them

50. Maxwell (1881:17-8) cites a Mentawei story in which crops and fruits came to humans through the agency of a spirit, which guarded the crops. It is not clear to me why he claims the spirit was said to be malevolent. 
to the next settlement is perceived to be long, leading to feelings of unease (Wessing 1978: 71;1995: 196).

In spite of educational changes and increasing religious pressures that have been taking place in Java, beliefs about spirits persist albeit that they are not always as publicly expressed as they once were (Andaya 2016: 258; Wessing 2013). Even where she is still acknowledged the rice-spirit has had to adapt to new conditions, as the pretty one (geulis) is now freely exchanged for the handsome one (kasep): rice is sold for cash, and men now sometimes cook if they are so inclined. With increased access to television young people now often know more about Sponge Bob than they do about wayang (puppet show) characters or the Queen of the Southern Ocean, Nyai Rara Kidul.

With the forests largely gone, the old cosmological narratives that explained them are fading. These narratives in any case were not immutable. While, as was mentioned earlier, our understandings about our physical and social environment come to us in the form of narratives (Somers 1994: 606, 613-4; Howell 2016:57), these are influenced by both the narrator's purposes (Pullman 2017: 64) and by the preoccupations of the listeners who inevitably shape the information they receive into coherent structures within which they locate themselves (Somers 1994: 614). Pullman (2017: 86), reflecting on Robert Frost's poem 'The Road Not Taken', likens tales to paths through a wood: at every fork in the path a choice must be made. These choices in turn determine how the narrative unfolds: 'anything can happen (and frequently does)'. In Java these forks have come in the form of changing religious convictions and scientific explanations, to which the old narratives have increasingly been adapted (Wessing 2006b, 1995). Yet, as we saw in Mr. Baier's data from South Banten, the old truths have not totally disappeared, and ongoing narratives present the participants with ever changing choices as their paths wind through their particular wood.

\section{Bibliography}

Abahalin, Andrew J. (2011). 'Sino-Pacifica': Conceptualizing Greater Southeast Asia as a SubArena of World History. Journal of World History 22(4): 659-691.

Ajip Rosidi (1973). My Experiences in Recording "Pantun Sunda". Indonesia 16: 105-111.

Andaya, Barbara Watson. (2016). Rivers, Oceans, and Spirits: Water Cosmologies, Gender, and Religious Change in Southeast Asia. TRaNS: Trans-Regional and-National Studies of Southeast Asia 4(2): 239-263.

Anderson, Benedict R. O'G. (1972). The Idea of Power in Javanese Culture. In: Claire Holt (ed.), Culture and Politics in Indonesia, pp.1-69. Ithaca: Cornell University Press.

Anonymous (1953). Hikajat Seri Rama. Djakarta: Balai Pustaka.

ASS (1990). Bamboo among the Sundanese. Voice of Nature 81(May): 34-37.

Baier, Randal E. (1985). The Angklung Ensemble of West Java: Continuity of an Agricultural Tradition. Balungan 2: 8-16.

Baier, Randal E. (1986). Si Duriat Keueung, the Sundanese Angklung Ensemble of West Java, Indonesia. M.A. Thesis, Wesleyan University. 
Barendregt, Bart and Robert Wessing (2008). Centered on the Source: Hamlets and Houses of Kanekes. In: R. Schefold, P.J.M. Nas, G. Domenig and R. Wessing (eds.), Indonesian Houses. Survey of Vernacular Architecture in Western Indonesia, pp. 551-596. Leiden: KITLV Press. [Verhandelingen van het Koninklijk Instituut voor Taal-, Land- en Volkenkunde 251.]

Becker, A.L. (1995). Beyond Translation. Essays Toward a Modern Philology. Ann Arbor: University of Michigan Press.

Brancaccio, Pia (1999). Añgulimāla or the Taming of the Forest. East and West 49 (1/4): 105118.

Chapman, F. Spencer (1973). The Jungle is Neutral. London: Gorki Books.

Coolsma, S. (1911). Soendaneesch-Hollandsch Woordenboek. Leiden: A.W. Sijthoff.

Creese, Helen (2004). Women of the Kakawin World. Marriage and Sexuality in the Indic Courts of Java and Bali. Armonk, NY: M.E. Sharpe.

Danasasmita et al. (ed.) (1977). Babad Pakuan atau Babad Pajajaran, 2 vols. Jakarta: Proyek Pengembangan Media Kebudayaan, Departemen Pendidikan dan Kebudayaan.

De Josselin de Jong, J.P.B. (1935). De Maleische Archipel als Ethnologisch Studieveld. Inaugural lecture on the occasion of his acceptance of the post of professor at the Rijksuniversiteit Leiden. Leiden: Universiteits-boekhandel en Antiquariaat J. Ginsberg.

Domenig, Gaudenz (2014). Religion and Architecture in Premodern Indonesia. Studies in Spatial Anthropology. Leiden: Brill. [Verhandelingen van het Koninklijk Instituut voor Taal-, Land- en Volkenkunde 294].

Dowson, John (1972). A Classical Dictionary of Hindu Mythology and Religion, Geography, History and Literature. London: Routledge and Kegan Paul.

Emigh, John (1996). Masked Performance. The Play of Self and Other in Ritual and Theatre. Philadelphia: University of Pennsylvania Press.

Endicott, Kirk (1979). Batek Negrito Religion. The Worldview and Rituals of a Hunting and Gathering People of Peninsular Malaysia. Oxford: Clarendon Press.

Enthoven, R.E. (1914). Folklore Notes. Vol. I - Gujarat. Compiled from materials collected by the late A.M.T. Jackson. Bombay: British India Press.

Eringa, F.S. (1949). Loetoeng Kasaroeng. Een mythologisch verhaal uit West-Java. 's-Gravenhage: Martinus Nijhoff. [Verhandelingen van het Koninklijk Instituut voor Taal, Land- en Volkenkunde, vol. VII].

Falk, Nancy E. (1973). Wilderness and Kingship in Ancient South Asia. History of Religions 13(1): 1-15.

Fuchs, Stephen (1960). The Gond and Bhumia of Eastern Mandla. London: Asia Publishing House.

Garna, Judistira Kartiwan (1988). Tangtu Telu Jaro Tujuh. Kajian Struktural Masyarakat Baduy di Banten Selatan, Jawa Barat Indonesia. Thesis, Fakulti Sains Kemasyarakatan dan Kemanusiaan Universiti Kebangsaan Malaysia, Bangi.

Gottowik, Volker (2018). Pilgrims, Prostitutes, and Ritual Seks. Heterodox Ritual Practices in the Context of the Islamic Veneration of Saints in Central Java. Bijdragen tot de Taal-, Land- en Volkenkunde 174: 393-421.

HAR (n.d.). Nyai Roro Kidul. Bandung: Citra Budaya.

Hara, Minoru (1973). The King as a Husband of the Earth. Asiatische Studien. Zeitschrift der Schweizerichen Gesellschaft für Asienkunde 27: 97-114.

Hardjadibrata, R. (2003). Sundanese English Dictionary. Jakarta: Pustaka Jaya.

Harimurti, A. (2017). Crowd, Vergadering, and Anticolonial Nationalism: Rampogan Sima and what made it Prohibited in Dutch East Indies. http://www.takusno.com/crowdvergadering-and-anticolonial-nationalism-rampogan-sima-and-what-made-it-prohibitedin-dutch-east-indies/. 
Hatib Ws. (1963). Arjo Menak Kawin dengan Bidadari. In: Urusan Adat-Istiadat dan Tjerita Rakjat Djawatan Kebudajaan Departemen P.D. dan K. (ed.), Tjerita Rakjat I, pp. 53-58. Djakarta: Balai Pustaka.

Hazeu, G.A.J. (1901). Nini Towong. Tijdschrift voor Indische Taal-, Land- en Volkenkunde 43: 36-107.

Heine-Geldern, Robert (1930). Weltbild und Bauform in Südostasien. Wiener Beitrage zur Kunst- und Kulturgeschichte Asiens 4: 28-78.

Heine-Geldern, Robert (1942). Conceptions of State and Kingship in Southeast Asia. Far Eastern Quarterly 2: 15-30.

Hefner Robert W. (1985). Hindu Javanese. Tengger Tradition and Islam. Princeton: Princeton University Press.

Hervey, D.F.A. (1882). The Mentra Traditions. Journal of the Straits Branch of the Royal Asiatic Society 10: 189-194.

Hidding, K.A.H. (1929). Nji Pohatji Sangjang Sri. Leiden: M. Dubbeldeman. [Dissertation, Rijksuniversiteit Leiden].

Holtzappel, C.J.G. (1986). Het Verband tusssen Desa en Rijksorganisatie in Prekoloniaal Java. Een Ontwikkelingssociologische Studie in Historisch Perspektief. Dissertation Rijksuniversiteit Leiden.

Howell, Signe (2016). Seeing and Knowing. Metamorphosis and the Fragility of Species in Chewong Animistic Ontology. In: Kai Århem and Guido Sprenger (eds.), Animism in Southeast Asia, pp. 55-72. New York and London: Routledge.

Jessup, Helen Ibbitson (1990). Court Arts of Indonesia. New York: The Asia Society Galleries/ Harry N. Abrams.

Kats, J. (1916). Dewi Çri. Tijdschrift voor Indische Taal-, Land- en Volkenkunde, 57: 177-199.

Kinsley, David (1986). Hindu Goddesses. Visions of the Divine Feminine in the Hindu Religious Tradition. Delhi: Motilal Banarsidass.

Knappert, Jan (1977). Myths and Legends of Indonesia. Singapore: Heineman Books.

Kummer, David M. and B.L. Turner (1994). The Human Causes of Deforestation in Southeast Asia. BioScience 44(5): 323-328.

Lombard, Denys (1974). La vision de la forêt à Java (Indonésie). Etudes Rurales 6: 475-485.

Mabuchi, Toichi (1954). Tales Concerning the Origin of Grains in Insular Areas of Eastern and Southeastern Asia. Asian Folklore Studies 23: 1-92.

Maxwell, W.E. (1881). Two Malay Myths: The Princess of the Foam, and the Raja of the Bamboo. London: Trübner and Co. Originally published in Journal of the Royal Asiatic Society of Great Britain and Ireland 13(4).

Monteanni, Luigi (2018). My Own Private Indonesian Shadow Box. Palm Wine 07 [on-line].

Mus, Paul (1975). India Seen from the East: Indian and Indigenous Cults in Champa, tr. and ed. I.W. Mabbett and D.P. Chandler. Clayton: Centre of Southeast Asian Studies, Monash University. [Monash Papers on Southeast Asia No. 3].

Nieuwenhuys, Rob and Frits Jaquet (1980). Java's onuitputtelijke natuur. Reisverhalen, tekeningen en fotografieën van Franz Wilhelm Junghuhn. Alphen aan den Rijn: A.W. Sijthoff.

Ochse, J.J. (1931). Indische Groenten. Met inbegrip van aardvruchten en kruiderijen. Batavia: Departement Landbouw, Nijverheid en Handel. Volkslectuur.

Olthof, W.L. (1987). Babad Tanah Djawi. Javaanse Rijkskroniek. Dordrecht: Foris Publications.

Panitia Kamus Lembaga Basa \& Sastra Sunda (1980). Kamus Umum Basa Sunda. Bandung: Tarate.

Paranavitana, S. (1970). Ploughing as a Ritual of Royal Consecration in Ancient Ceylon. In: Himansu Bhusan Sarkar (ed.), H.C. Majumdar Felicitation Volume, pp. 31-39. Calcutta: K.L. Mukhopadhyay. 
Pemberton, John (1994). On the Subject of "Java". Ithaca: Cornell University Press.

Pigeaud, Theodore G. Th. (1968). Literature of Java, vol. 2. The Hague: Martinus Nijhoff.

Platenkamp, Jos. D. M. (2007). Spirit Representations in Southeast Asia: a Comparative View. In: Frédéric B. Laugrand and Jarich G. Oosten (eds.), La Nature des Esprits dans les Cosmologies Autochtones/Nature of Spirits in Aboriginal Cosmologies, pp. 99-129. Québec: Les Presses de L'université Laval.

Pleyte, C.M. (1905). Pa Sakiran, de zanger. In: C.M. Pleyte (ed.), Soendasche Schetsen. Bandoeng: C. Kolff and Co.

Pleyte, C.M. (1910). De legende van den Loetoeng Kasaroeng. Een gewijde sage uit Tji-rebon. Batavia: Albrecht and Co./ 's-Gravenhage: Martinus Nijhoff. [Verhandelingen van het Bataviaasch Genootschap van Kunsten en Wetenschappen, vol. LVIII, part 3].

Prawirasuganda, A. (1964). Upatjara Adat di Pasundan. Bandung: Sumur Bandung.

Proyek Penelitian dan Pencatatan Kebudayaan Daerah (1978). Cerita Rakyat Daerah Kalimantan Timur. Jakarta: Departemen Pendidikan dan Kebudayaan.

Proyek Penerbitan dan Pencacatan Kebudayaan Daerah (1981). Cerita Rakyat Jawa Timur. Jakarta: Departemen Pendidikan dan Kebudayaan, Proyek Penerbitan Buku Sastra Indonesia dan Daerah.

Pullman, Philip (2017). Daemon Voices. Essays on Storytelling. Simon Mason (ed.). Oxford: David Fickling Books.

Purwadi (2004). Sejarah Asal-Usul Nenek Moyang Orang Jawa. Jogjakarta: Tunas Harapan.

Rassers, W.H. (1959). Pañji the Culture Hero. A Structural Study of Religion in Java. The Hague: Martinus Nijhoff. [Koninklijk Instituut voor Taal-, Land- en Volkenkunde, Translation Series 3].

Robson, Stuart and Singgih Wibisono (2002). Javanese English Dictionary. Hongkong: Periplus.

Sagimun M.D. (1963a). Pandji Kelaras. In: Urusan Adat-Istiadat dan Tjerita Rakjat Djawatan Kebudajaan Departemen P.D. dan K. (ed.), Tjerita Rakjat I, pp. 167-172. Djakarta: Balai Pustaka.

Sagimun M.D. (1963b). Tiga Piatu. In: Urusan Adat-Istiadat dan Tjerita Rakjat Djawatan Kebudajaan Departemen P.D. dan K. (ed.), Tjerita Rakjat I, pp. 107-130. Djakarta: Balai Pustaka.

Satjadibrata, R. (1954). Kamus Basa Sunda. Djakarta: Perpustakaan Perguruan Kementrian P.P. dan K.

Schefold, Reimar (1989). De natuur als cultuur van gene zijde: tribale concepten van 'natuur' in Indonesië. Anthropologische Verkenningen 7(4): 5-22.

Schnepel, Burkhard (1995). Durga and the King: Ethnohistorical Aspects of Politico-Ritual Life in a South Orissan Kingdom. Journal of the Royal Anthropological Institute 1(1): 145-166.

Seno-Sastroamidjojo, A. (1962). Obat Asli Indonesia. Djakarta: Pustaka Rakjat.

Sentot Js. (1990). Menjaring Rezeki Lewat Seks Bebas: Gunung Kemukus Semakin Panas. Liberty 37 (1734): 28-29, 60-61.

Shulman, David (1980). The Green Goddess of Tirumullaivāyil. East and West 30(1/4): 117131.

Smith, Bianca J. and Mark Woodward (2016). Magico-spiritual Power, Female Sexuality and Ritual Sex in Muslim Java: Unveiling the Kesekten of Magical Women. The Australian Journal of Anthropology 27 (3): 317-332.

Soebardi, S. (1975). The Book of Cabolèk. A critical edition with introduction, translation and notes. A contribution to the study of Javanese mystical tradition, The Hague: Martinus Nijhoff [Bibliotheca Indonesica No. 10].

Solis, Thania (2017). Southeast Asia Deforestation Effects RA4. https://history.libraries.wsu. edu/spring2017/2017/01/19/research-assignment-1-3/. 
Somers, Margaret R. (1994). The Narrative Construction of Identity: A Relational and Network Approach. Theory and Society 23: 605-649.

Stutley, Margaret and James Stutley (1977). Harper's Dictionary of Hinduism. Its Mythology, Folklore, Philosophy, Literature, and History. New York: Harper and Row.

Subiyanto Hr (ed.) (n.d.). Misteri Nyai Lara Kidul. Solo: Mayasari.

Sutarto, Ayu, Marwoto, and Heru SP. Saputra (2010). Mutiara yang Tersisa I: Kearifan Lokal dalam Cerita Rakyat Madura. Jember: Kompyawisda Jatim.

Tambiah, S.J. (1970). Buddhism and the Spirit Cults in North-East Thailand. Cambridge: Cambridge University Press. [Cambridge Studies in Social Anthropology No. 2].

Termorshuizen, Gerard (ed.) (1993). In de binnenlanden van Java. Vier negentiende-eeuwse reisverhalen. Leiden: KITLV Press.

Van der Horst van Doorn, G. C. (1929). Indische sprookjes legenden en fabelen. Den Haag: Van Goor.

Van Zanten, Wim (2016). Some Notes on the Pantun Storytelling of the Baduy Minority Group. Its Written and Audiovisual Documentation. Wacana 17 (3): 404-437.

Wessing, Robert (1974). Language Levels in Sundanese. Man 9(1): 5-22.

Wessing, Robert (1978). Cosmology and Social Behavior in a West Javanese Settlement. Athens, OH: Ohio University Center for International Studies, Southeast Asia Program. [Papers in International Studies, Southeast Asia Series No. 47].

Wessing, Robert (1986a). The Soul of Ambiguity: The Tiger in Southeast Asia. Monograph Series on Southeast Asia, Special Report No. 24. DeKalb, IL: Center for Southeast Asian Studies, Northern Illinois University.

Wessing, Robert (1986b). Wearing the Cosmos: Symbolism in Batik Design. Crossroads 2(3): 40-82.

Wessing, Robert (1988). The Gunongan in Banda Aceh, Indonesia: Agni's Fire in Allah's Paradise? Archipel 35: 157-194.

Wessing, Robert (1990). Sri and Sedana and Sita and Rama: Myths of Fertility and Generation. Asian Folklore Studies 49(2): 235-257.

Wessing, Robert (1991). An Enclosure in the Garden of Love. Journal of Southeast Asian Studies 22(1): 1-15.

Wessing, Robert (1995). The Last Tiger in East Java: Symbolic Continuity in Ecological Change. Asian Folklore Studies 54: 191-218.

Wessing, Robert (1997). A Princess from Sunda. Some Aspects of Nyai Rara Kidul. Asian Folklore Studies 56: 317-353.

Wessing, Robert (1999). The Sacred Grove: Founders and the Owners of the Forest in West Java, Indonesia. In: S. Bahuchet, D. Bley, H. Pagezy and N. Vernazza-Licht (eds.), L'Homme et la forêt tropicale, pp. 59-74. Travaux de la Société d'Écologie Humaine. Chateauneuf-de-Grasse: Editions de Bergier.

Wessing, Robert (2003). The Kraton-city and the Realm. Sources and Movement of Power in Java. In: Peter J.M. Nas, Gerard A. Persoon and Rivke Jaffe (eds.), Framing Indonesian Realities. Essays in Symbolic Anthropology in Honour of Reimar Schefold, pp. 199-250. Leiden: KITLV Press. [Verhandelingen van het Koninklijk Instituut voor Taal-, Land- en Volkenkunde 209].

Wessing, Robert (2006a). A Community of Spirits: People, Ancestors and Nature Spirits in Java. Crossroads 18(1): 11-111.

Wessing, Robert (2006b). Homo Narrans in East Java. Regional Myths and Local Concerns. Asian Folklore Studies 65: 45-68.

Wessing, Robert (2007). Dislodged Tales. Javanese Goddesses and Spirits on the Silver Screen. Bijdragen tot de Taal, Land- en Volkenkunde 163(4): 529-555.

Wessing, Robert (2011). Tarumanagara: What's in a Name? Journal of Southeast Asian Studies 42(2): 325-337. 
Wessing, Robert (2013). The Osing Agricultural Spirit-Medium. Moussons 22(2): 111-124.

Wessing, Robert (2016). Nyai Rara Kidul. The Antecedents of a Cosmopolitan Queen. Anthropos 111: 371-393.

Wessing, Robert (2017). The Lord of the Land Relationship in Southeast Asia. In: Andrea Acri, Roger Blench, and Alexandra Landmann (eds.), Spirits and Ships: Cultural Transfers in Early Monsoon Asia, pp. 515-556. Singapore: ISEAS - Yusof Ishak Institute.

Wessing, Robert and Bart Barendregt (2005). Tending the Spirit's Shrine: Kanekes and Pajajaran in West Java. Moussons 8: 3-26.

Widyatmanta (1963). Djaka Tarup. In: Urusan Adat-Istiadat dan Tjerita Rakjat Djawatan Kebudajaan Departemen P.D. dan K. (ed.), Tjerita Rakjat I, pp. 67-72. Djakarta: Balai Pustaka.

Wilken, G.A. (1912). De Verspreide Geschriften van Prof. Dr. G.A. Wilken, vol. 3. Semarang: G.C.T. van Hoeve.

Winstedt, R.O. (1929). The Perak Genies. Journal of the Malayan Branch of the Royal Asiatic Society 7(3): 460-466.

Winstedt, R.O. (1945). Kingship and Enthronement in Malaya. Journal of the Royal Asiatic Society (3+4): 134-145.

Woodroffe, John (1975). Śakti and Śākta. Madras: Ganesh and Co.

Work, Courtney (2018). Chthonic Sovereigns? 'Neak Ta' in a Cambodian Village. The Asia Pacific Journal of Anthropology https://doi.orh/10.1080/14442213.2018.1553205.

Zieseniss, Alexander (1963). The Rama Saga in Malaysia. Its Origin and Development. Singapore: Malaysian Sociological Research Institute.

Zoetmulder, P.J. (1982). Old Javanese-English Dictionary, part 1 (A-O) \& 2 (P-Y). 'S-Gravenhage: Martinus Nijhoff. [Koninklijk Instituut voor Taal-, Land- en Volkenkunde].

Zulkarnaen, M. Yusuf (1987). Aryo Menak. Legenda dari Madura. Bandung: Pionir Jaya. 
